\title{
Matando a escrava que vive em nós ${ }^{*}$
}

\author{
Marilia Novais da Mata Machado**
}

Preconceito contra a "mulher" é livro tão complexo, sério $e$ denso quanto a questão da qual se ocupa. Resenhá-lo é, assim, um risco, é criar outro discurso, calcado no primeiro, ao qual se deseja ser fiel, mas é, também, um desvio, uma interpretação, uma fala feita de outro lugar, também feminino, também sem pretensão à verdade, intencionalmente, tão pouco unívoco quanto o que o gerou.

O livro de Sandra Azerêdo é aberto, poético, desafiante, e convida à aventura, a trilhar e desbravar caminhos ainda desconhecidos, a redesenhar fronteiras, a re-significar cotidianos, sem garantia e sem intento de chegar a certezas. Pequenos sinais e sugestões já apontam para questões importantes, construções e desconstruções em ato. Assim, as aspas no título sinalizam uma fronteira nova que deixa de fora a busca da mulher como essência $e$ se abre à polissemia do feminino. A menção à diferença, também no título, aponta para "um dos poucos caminhos para a igualdade" (35), frase que sugere que há, contudo, outros caminhos: a poesia, a arte, a coragem, a escrita, o desafio, a visualização de limites a serem ultrapassados.

Três temas organizam o livro: (1) o tratamento do preconceito como um conceito construído histórica $e$ discursivamente e a importância da afirmação da diferença como instrumento/arma para desmontar essa construção; (2) os meandros da fabricação dos conceitos de mulher e de diferença

\footnotetext{
" AzERÊDO, Sandra. Preconceito contra a "mulher": Diferença, poemas e corpos. São Paulo,Cortez, 2007, 120p. Recebida para publicação em agosto de 2007, aceita em setembro de 2007.

*** Doutora pela Universidade Paris Norte; professora da Faculdade Novos Horizontes, Belo Horizonte, MG. marilianmm@terra.com.br
} 
Matando a escrava que vive em nós

sexual em fragmentos da filosofia ocidental; (3) a teoria feminista e o conceito de mulher.

Tratando o primeiro tema, Sandra Azerêdo acentua o papel da linguagem na constituição das coisas. Muito cedo na vida, em cada lugar e em cada época, a linguagem ensina e naturaliza certa diferença sexual, em cada caso puramente imaginária. Junto à diferença, a linguagem cria também uma certa mulher, um certo homem e, embora não necessariamente, o preconceito. Entre nós, cria um lugar privado para a primeira (as fronteiras da casa, a proteção da família), público para o segundo (a rua, a experiência da liberdade), uma posição de domínio, independência $e$ autonomia para ele, a sujeição, dependência, alienação $e$ submissão para ela. Cria dicotomias: a mulher de verdade (esposa abnegada que vive para o marido e o lar) / a outra (a consumista, a puta); o macho com a prerrogativa do intelecto / a fêmea enclausurada no próprio corpo que é o que a define.

Sobre dicotomias como as citadas, o preconceito se instala. Um protótipo pode ser representado pelo triângulo pai provedor, mãe dona-de-casa, a puta da outra. Esse triângulo é parte do imaginário de cada um, de forma que poucas coisas são mais ultrajantes, para uma mãe/mulher de verdade, que ser chamada de puta pelo pai provedor. Para os três, o triângulo representa lugares naturais e identidades compactas, graníticas, como a do macho insaciável, da mulher honesta e daquela que não presta. Reinando, o homem; quanto a elas, sujeitas à consciência hospedeira do opressor, para utilizar a expressão criada por Paulo Freire.

São justamente essas identidades compactas que a autora pretende quebrar, re-esculpir, desnaturalizar, produzindo um outro saber (crítico e responsável), outro imaginário radical (instituinte), questionando, buscando ser capaz de, cada vez mais, fazer perguntas pertinentes, numa linguagem agora libertadora, apontando a polissemia das palavras, tecendo novas conexões.

Ora, se a linguagem é capaz de construir discursivamente diferenças sexuais que são estereótipos e identidades graníticas 
vinculadas, na vida real, a preconceitos que no limite são violências contra a mulher - estupros, assassinatos, abusos, espancamentos, insultos, ameaças e desrespeitos a direitos, isso tudo em um contexto de grande dominação (capitalista, falocêntrica), ela é capaz também de construir o discurso libertador, no qual as diferenças, agora afirmadas, apontam para a multiplicidade de gêneros, raças e classes, para a polissemia do conceito de mulher, para a alteridade a ser reconhecida $e$ não isolada e dominada.

Abordando o segundo tema, Sandra Azerêdo seleciona no pensamento filosófico ocidental herdado por nós exemplos de construção do conceito de mulher. Em Espinosa, encontra a mulher naturalizada, compactada, enquadrada, inferior ao homem, governada por ele no mundo todo e, só assim, para o filósofo, vivendo harmoniosamente (a autora disseca essa tese, apontando, entre muitos outros vieses, a sujeição da mulher nela implicada). Em Freud encontra a mulher invejosa do pênis, falando sempre de si a partir da referência masculina, mas - um avanço - figura enigmática que demonstra que existe um limite no saber psicanalítico. Em Nietzsche, claramente, a mulher é um conceito criado, construído, e esse pensamento é pertinente para uma teoria feminista. O importante insight de Beauvoir - "Não se nasce mulher, torna-se mulher" - abre-se também para uma teoria feminista; mas a reflexão desta filósofa, quando esmiuçada e desconstruída, mostra temores de avançar no sentido da liberdade, um acrítico querer assimilar-se ao homem, além de propostas implícitas de vanguardismo que, ao colocar mulheres intelectuais na linha de frente, aliena todas as outras. Já Foucault adota um pensamento múltiplo, filia-se metodologicamente à genealogia nietzschiana, dá ênfase à história e ao corpo e acusa a construção assimétrica, separando homem e mulher no que diz respeito à reflexão moral sobre o comportamento sexual.

O pensamento de Foucault, Deleuze, Guattari, Rolnik, Rancière, Haraway completa a própria reflexão da autora, colaborando na construção de uma teoria feminista em que a 
Matando a escrava que vive em nós

diferença sexual, de raça e de classe é afirmada, não em defesa de uma essência de mulher - alguém mais sensível, mais intuitiva, menos agressiva - mas para desconstruir essa suposta essência. Pois a busca de origens e essências constitui uma posição escorregadia, talvez mentirosa, discurso fundado na fala masculina, formador de identidades estereotipadas e, portanto, presas fáceis da opressão e do preconceito. Não há uma essência de mulher maciça, homogênea, mas mulheres singulares, múltiplas, capazes de exercer sua autonomia.

A teoria feminista é desenvolvida como terceiro tema. Sandra Azerêdo aponta para a singularidade das mulheres no mundo capitalista, falocêntrico e racista, assinala a necessidade de ousar teoricamente, afirmando a diferença, abrindo-se para a poesia, a literatura, a arte, usando a linguagem da construção/ desconstrução. A autora chama a atenção para a importância da contribuição das mulheres não brancas, muitas delas lésbicas, que foram capazes de criticar o racismo, a homofobia e o colonialismo nos escritos das mulheres intelectuais e brancas do Primeiro Mundo. Para tanto, essas mulheres usaram uma linguagem de resistência, inovadora, pouco canônica, polêmica, às vezes, à custa de serem isoladas nas suas universidades. Mas foi justamente esse tipo de produção - da qual são exemplos Anzaldúa e Irigaray - que permitiu desconstruir conceitos fundamentais à manutenção do preconceito. Quatro desses conceitos são tratados, no livro, com detalhes: gênero, identidade, diferença, experiência.

Ầ medida que desenvolve seus argumentos, Sandra Azerêdo lança mão da poesia, da análise de romances e filmes e, especialmente, de informações de primeira mão, obtidas com sua pesquisa com mulheres vítimas de violência. Pouco a pouco fica claro que essas mulheres constroem suas subjetividades a partir da violência, fechando-se a re-significações do que vivem e a tudo que ameaça a hegemonia masculina. Para lidar com essas situações de total absorção do discurso dominante e enfrentar o preconceito contra a mulher e a violência que o acompanha, 
Sandra Azerêdo lança mão da noção de "amizade como modo de vida", proposta por Foucault, e realiza essa amizade em ato no grupo das faladeiras, constituído em uma delegacia de mulheres de Belo Horizonte. Cria, assim, uma metodologia de combate ao preconceito contra a mulher.

Resenhas (como a aqui apresentada) cobrem muito pouco da riqueza de uma obra. Assim, é bom insistir, Preconceito contra a "mulher" é leitura indispensável para todos aqueles que quiserem filiar-se ao movimento de combate a preconceitos $e$, sobretudo, para todas as que quiserem, parafraseando Mia Couto, matar a escrava que vive dentro de nós. 